\title{
A Scalable Synthesis of the Difluoromethyl-allo-threonyl Hydroxamate-Based LpxC Inhibitor LPC-058
}

\author{
Xiaofei Liang, ${ }^{\dagger}$ Ramesh Gopalaswamy, ${ }^{*},^{\dagger}$ Frank Navas, III, ${ }^{\dagger}$ Eric J. Toone, ${ }^{\dagger, \ddagger}$ and Pei Zhou*, ${ }^{\dagger, \neq}$ \\ ${ }^{\dagger}$ Department of Chemistry, Duke University, Durham, North Carolina 27708, United States \\ ${ }^{\ddagger}$ Department of Biochemistry, Duke University Medical Center, Durham, North Carolina 27710, United States
}

\section{Supporting Information}

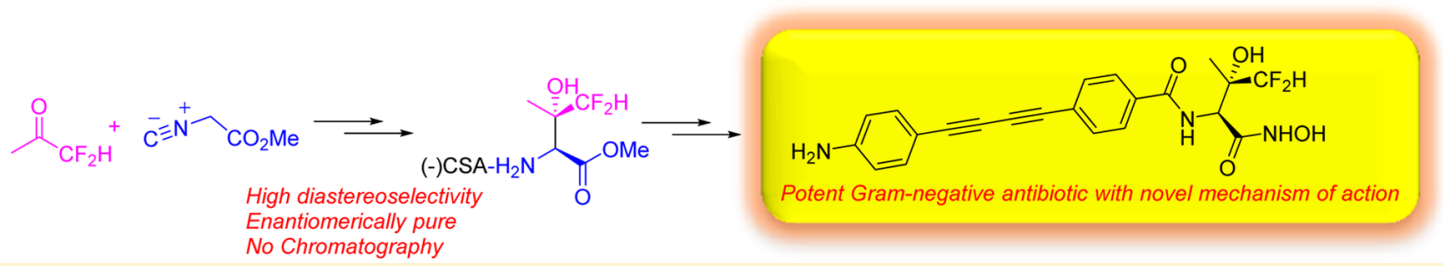

ABSTRACT: The difluoromethyl-allo-threonyl hydroxamate-based compound LPC-058 is a potent inhibitor of UDP-3-O-(R-3hydroxymyristoyl)- $N$-acetylglucosamine deacetylase $(\mathrm{LpxC})$ in Gram-negative bacteria. A scalable synthesis of this compound is described. The key step in the synthetic sequence is a transition metal/base-catalyzed aldol reaction of methyl isocyanoacetate and difluoroacetone, giving rise to 4-(methoxycarbonyl)-5,5-disubstituted 2-oxazoline. A simple NMR-based determination of enantiomeric purity is also described.

$\mathrm{T}$ he alarming rise of antimicrobial resistance ${ }^{1-3}$ of Gramnegative pathogens has become a serious threat to public health and highlights the urgent need for antibiotics with novel modes of action. The UDP-3-O-(R-3-hydroxymyristoyl)- $N$ acetylglucosamine deacetylase $(\mathrm{LpxC})$ is a novel, validated antibiotic target against Gram-negative pathogens. ${ }^{4}$ The enzyme catalyzes the committed step in the biosynthesis of lipid A, the membrane anchor of lipopolysaccharide and the predominant lipid component of the outer leaflet of the Gram-negative outer membrane. We have previously reported the design of potent LpxC inhibitors containing a difluoromethyl-allo-threonyl hydroxamate headgroup. ${ }^{4}$ This series of compounds, represented by LPC-058, displays broad-spectrum antibiotic activity against antibiotic resistant Gram-negative pathogens, thereby highlighting the therapeutic potential of this class of LpxC inhibitors. Herein, we describe a scalable and stereoselective synthesis of LPC-058, which sets the stage for preclinical in vivo studies of this novel series. ${ }^{4}$

The initial medicinal chemistry route for the synthesis of LPC-058 is shown in Scheme 1. The diacetylene carboxylic acid 4 was prepared in two steps from methyl-4-ethynyl benzoate (1). The first step employed modified Glaser reaction ${ }^{5,6}$ conditions under which an excess of 4-ethylnylbenzenamine 2 (5 equiv) and copper(II) acetate ( 2 equiv) in the presence of piperidine in dichloromethane (DCM) provided 3 in a low yield (35\%). ${ }^{7}$ Subsequent alkaline hydrolysis of ester 3 provided the diacetylene carboxylic acid 4 in quantitative yield.

We recently published the medicinal chemistry route for (2S,3S)-3-difluoromethylthreonine methyl ester 11, which was generated in six steps starting from $(S)$-1-methyl-4(methylsulfinyl)benzene (Scheme 1). ${ }^{4}$ Our synthetic strategy for amino ester 11 was adapted from a published procedure for the corresponding monofluoro analogue. ${ }^{8}$ The copper(I)catalyzed $[2+3]$ cycloaddition reaction between methyl isocyanoacetate and ( $S$ )-1,1-difluoro-3-( $p$-tolylsulfinyl)propan2-one (6) provided oxazoline 7 as a mixture of diastereomers. The desired diastereoisomer of oxazoline 7 (i.e., $4 S, 5 S, S_{S}$ ) is the less polar spot on TLC with $R_{f} \sim 0.35$ [EtOAc/hexanes (2:3)] and was isolated by flash chromatography [EtOAc/hexanes (0$40 \%)$ ] as the major product in $45 \%$ yield. Oxazoline 7 was readily hydrolyzed in a chloroform/water mixture at room temperature to give the amido ester $\mathbf{8}$ in near quantitative yield. Sulfoxide 8 was reduced to corresponding sulfide 9 by using trifluoroacetic anhydride with sodium iodide in acetone at -40 ${ }^{\circ}$ C. ${ }^{9}$ Desulfurization of 9 with a Raney nickel-sodium hypophosphite system provided the (2S,3S)-3-difluoromethylthreonine derivative (10), which upon mild acidic hydrolysis afforded (2S,3S)-3-difluoromethylthreonine methyl ester $11 .^{10}$

Amino ester 11 was reacted with diacetylene carboxylic acid 4 under standard coupling conditions to give amide ester $\mathbf{1 2}$. Treatment of $\mathbf{1 2}$ with hydroxylamine under alkaline conditions afforded desired hydroxamate LPC-058. ${ }^{4}$

A number of factors made this approach unsuitable for delivering substantial quantities (>100 g) of LPC-058. The major drawback of this strategy is the tedious chromatographic separation of oxazoline 7 from its diastereomers. Furthermore, chiral sulfoxide 5 is very expensive or has to be prepared. ${ }^{11}$ Finally, the copper-catalyzed cross-coupling of methyl 4ethynylbenzoate $\mathbf{1}$ with excess 4-ethylnylbenzenamine $\mathbf{2}$ is complicated by the formation of homocoupled products that

Received: March 19, 2016

Published: April 29, 2016 


\section{Scheme 1. Initial Route to LPC-058}

\section{Synthesis of diacetylene carboxylic acid}

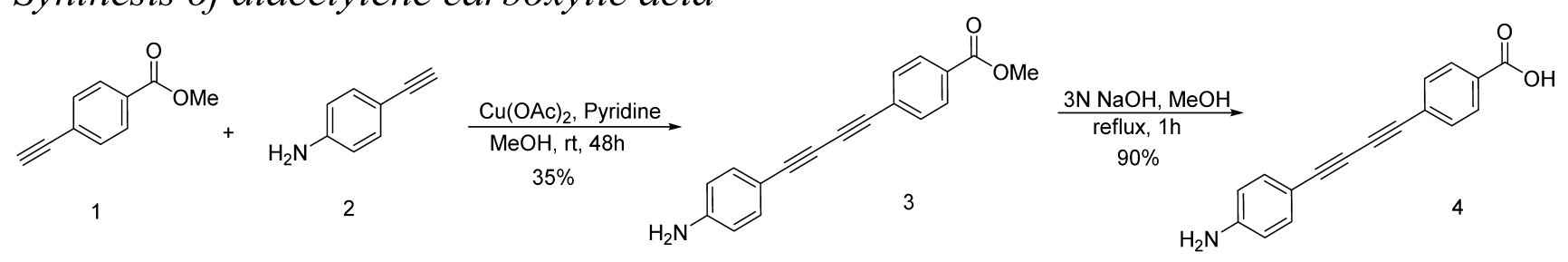

\section{Synthesis of the difluoro-threonine methyl ester ${ }^{4}$}

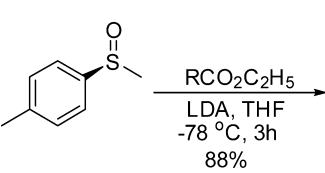

5<smiles>Cc1ccc(S(=O)CC(=O)C(F)(F)F)cc1</smiles>

6

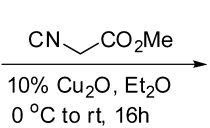

$45 \%$

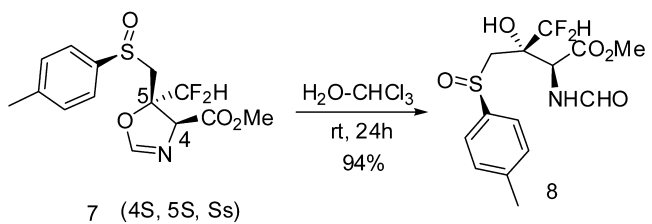

$7 \quad(4 \mathrm{~S}, 5 \mathrm{~S}, \mathrm{Ss})$

$$
+ \text { other diastereomers }
$$
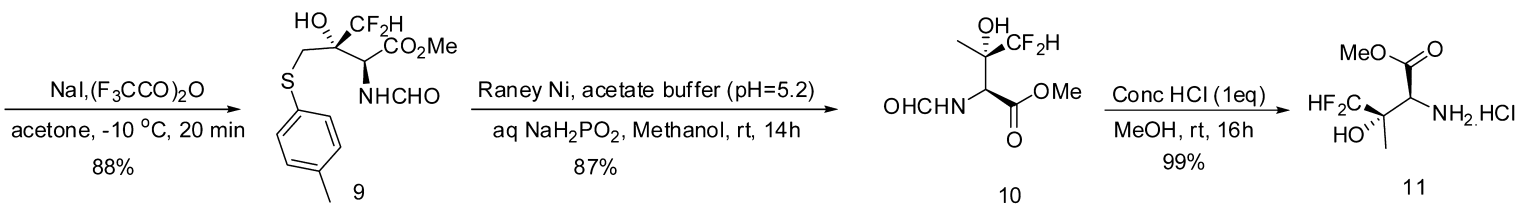

\section{Synthesis of LPC-058}

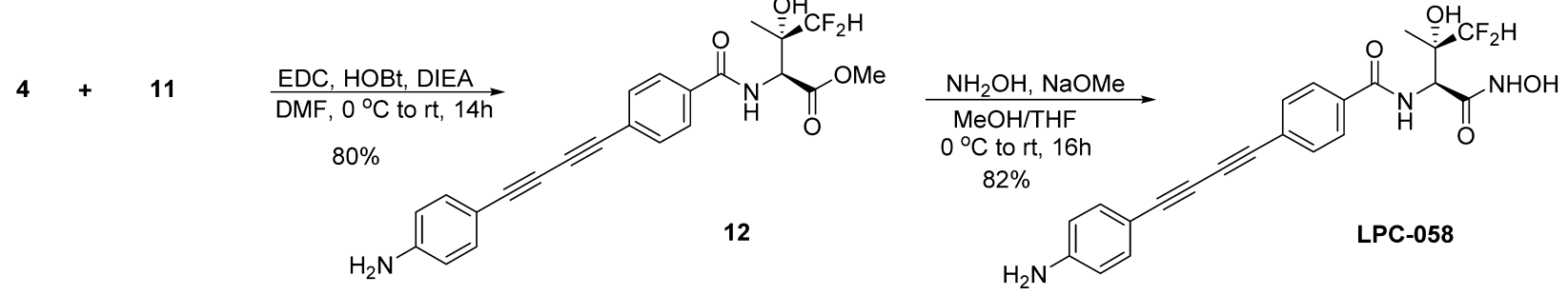

Scheme 2. Synthesis of Diyne Carboxylic Acid 4

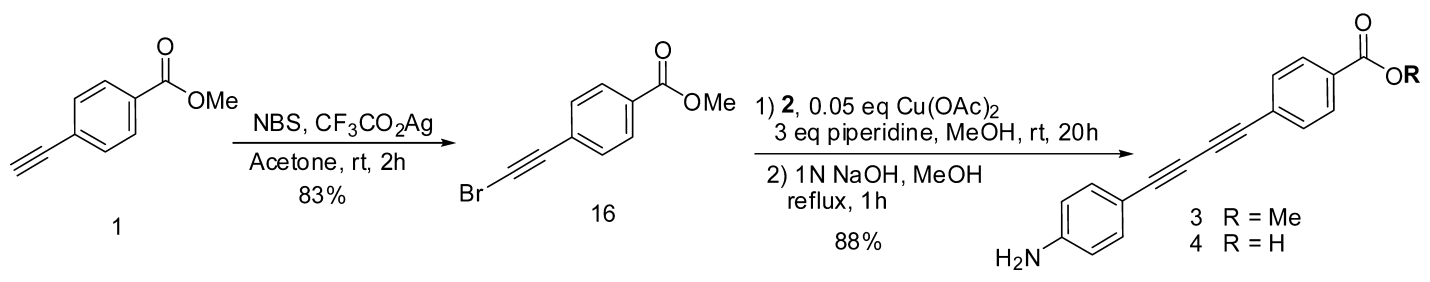

require tedious chromatographic separation. Therefore, we directed our attention to developing efficient and scalable routes to the key intermediates (2S,3S)-3-difluoromethylthreonine methyl ester 11 and diacetylene carboxylic acid $\mathbf{4}$.

Synthesis of unsymmetrical diynes has recently been the subject of extensive research. A survey of the literature indicates that diynes can be formed under various conditions, and many useful methods have been reported. ${ }^{12-16}$ In 2010, Balaraman et al. improved the synthesis of symmetrical and unsymmetrical 1,3-diynes by employing catalytic amounts ( 0.1 equiv) of copper(II) acetate in the presence of a stoichiometric amount of piperidine in 1,2-dichloroethane under aerobic conditions. ${ }^{12}$ With this method, the yield of unsymmetrical 1,3-diyne 3 was $>60 \%$ (an improvement over that described above); however, unfortunately, it still involved 5 equiv of 4-ethylnylbenzenamine 2 , and homocoupled byproducts remained a problem.
Efficient syntheses of unsymmetrical diynes using an alkynyl halide and a terminal alkyne have been reported. ${ }^{14,15}$ To reduce the need for excess 4-ethylnylbenzenamine 2, we replaced methyl 4-ethynylbenzoate 1 with methyl 4-(bromoethynyl)benzoate $16^{17}$ as described in Scheme 2. Treatment of methyl 4ethynylbenzoate $\mathbf{1}$ with $\mathrm{N}$-bromosuccinimide in the presence of silver trifluoroacetate as a catalyst provided 4-(bromoethynyl)benzoate $16^{17}$ in $83 \%$ yield. The reaction of $\mathbf{1 6}$ with a nearstoichiometric amount of 4-ethynylbenzenamine 2 (1.05 equiv) and copper(II) acetate ( 0.05 equiv) as a catalyst in the presence of piperidine proceeded efficiently to give diyne 3 ( $92 \%$ yield). In the scale-up process, crude intermediate $\mathbf{3}$ was hydrolyzed to give diacetylene acid $\mathbf{4}$ without purification.

We next turned our attention to the large scale synthesis of (2S,3S)-3-difluoromethylthreonine methyl ester 11. The chiral sulfoxide-controlled stereoselective synthesis of optically pure 


\section{Scheme 3. Synthesis of Amine}
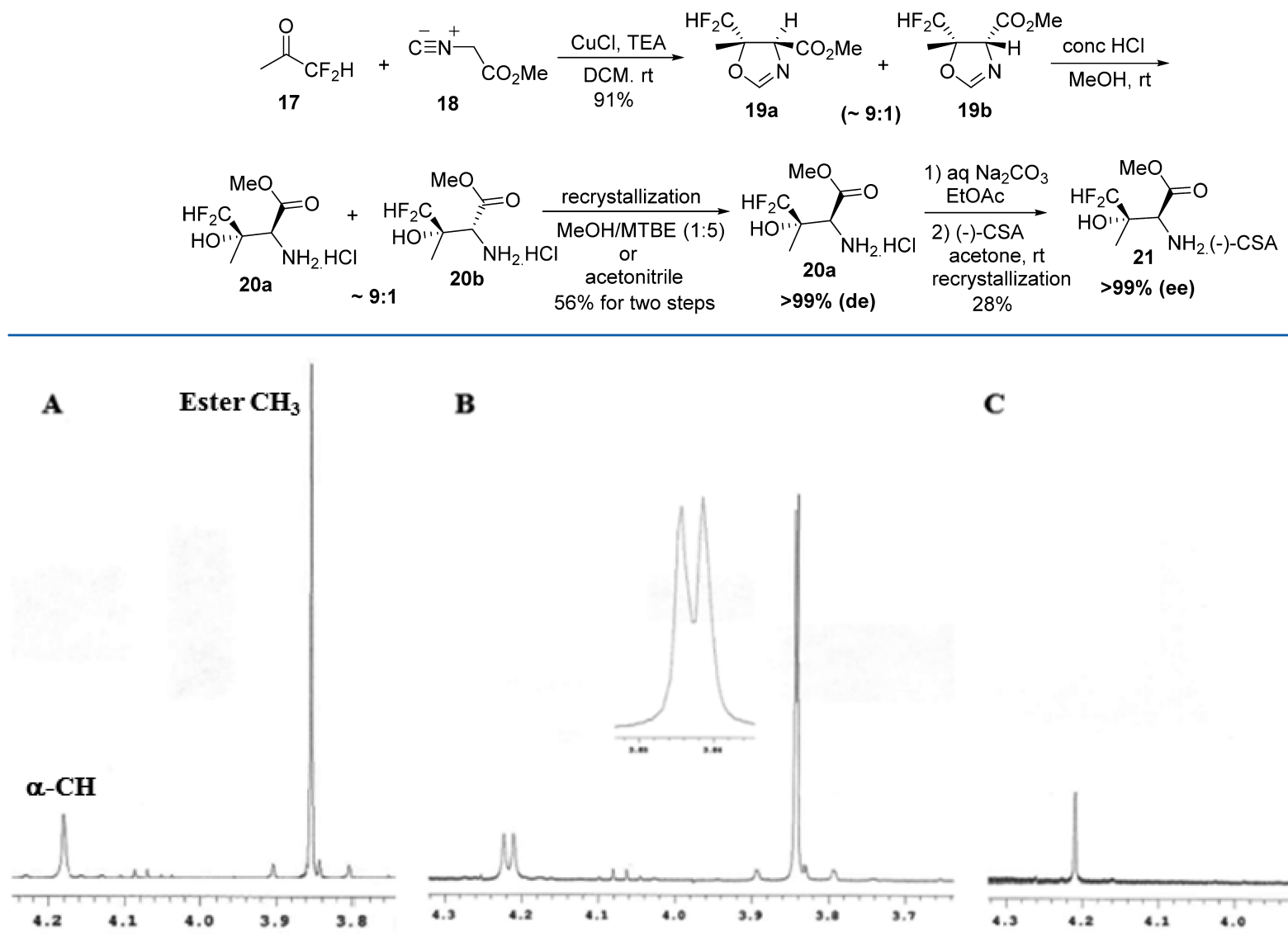

$\mathbf{B}$

\section{C}
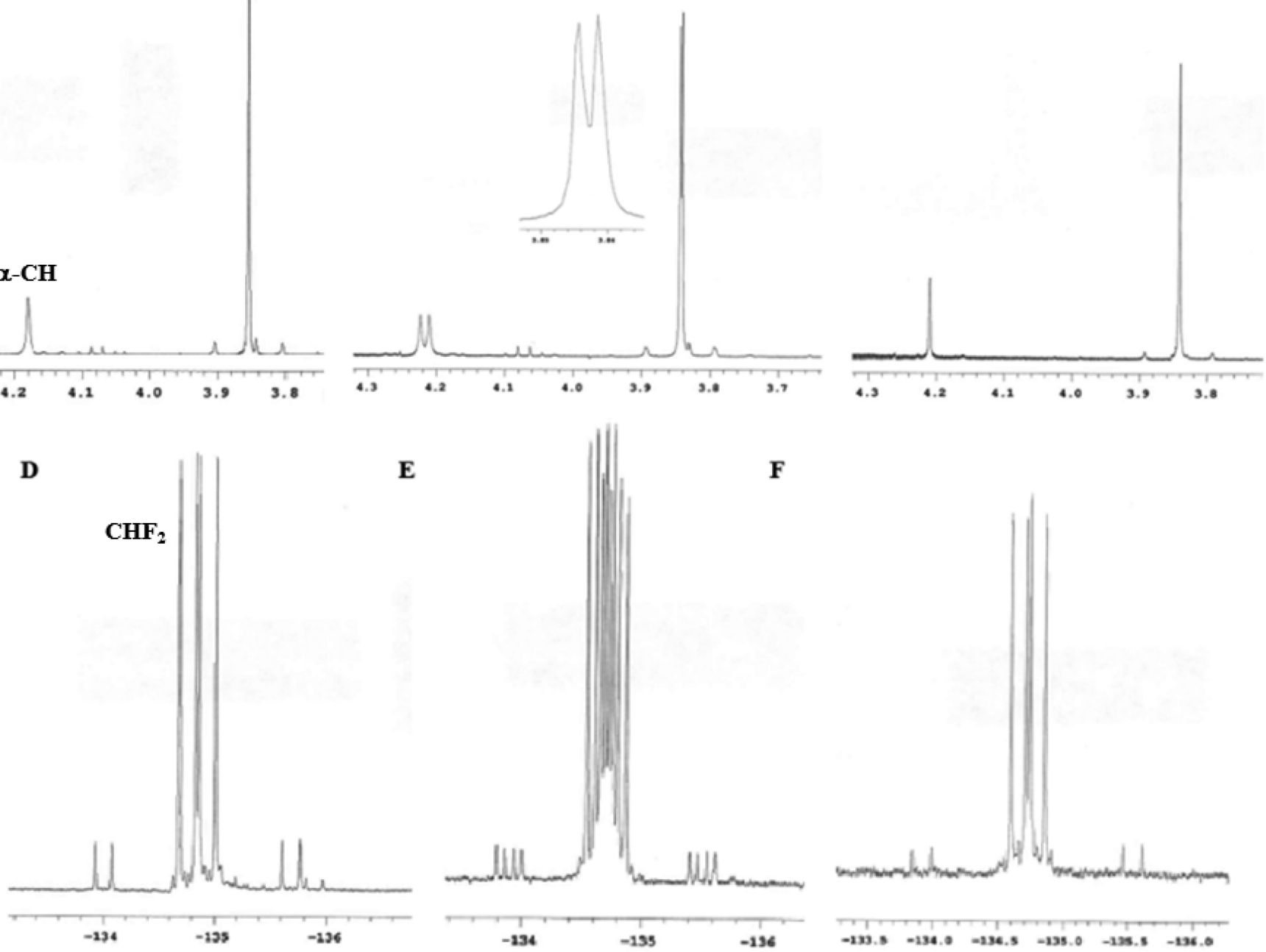

Figure 1. (A and D) Racemic hydrochloride salt 20a in $\mathrm{CD}_{3} \mathrm{OD}$. (B and $\mathrm{E}$ ) Racemic hydrochloride salt 20a in the presence of a 10-fold excess of $(+)$-tartaric acid in $\mathrm{CD}_{3} \mathrm{OD}$. (C and F) Recrystallized optically pure sample of 21 in the presence of a 10 -fold excess of $(+)$-tartaric acid in $\mathrm{CD}_{3} \mathrm{OD}$. (A-C) ${ }^{1} \mathrm{H}$ spectra and $(\mathrm{D}-\mathrm{F}){ }^{19} \mathrm{~F}$ spectra.

(2S,3S)-3-difluoromethylthreonine methyl ester 11 (Scheme 1) is efficient and useful on a small scale. However, on a large scale, this approach has significant drawbacks, including (1) the high cost of (S)-1-methyl-4-(methylsulfinyl)benzene, (2) the fact that there was only a single crystalline intermediate in the sequence (i.e., chiral difluoroacetone 6), and (3) the low boiling point of trifluoroacetic anhydride that can be a safety concern when it is used in large scale reactions. Taken together, these concerns led us to re-evaluate our strategy. During the development of an alternative scalable route, our main objectives were (a) to address the safety issues, (b) to enhance the robustness of the synthetic route, and (c) to devise a sequence that had the potential for additional crystalline intermediates to facilitate purification by recrystallization. We took advantage of the well-documented transition metal/basecatalyzed aldol reaction to construct oxazolines in a stereo- 


\section{Scheme 4. Amide Coupling}
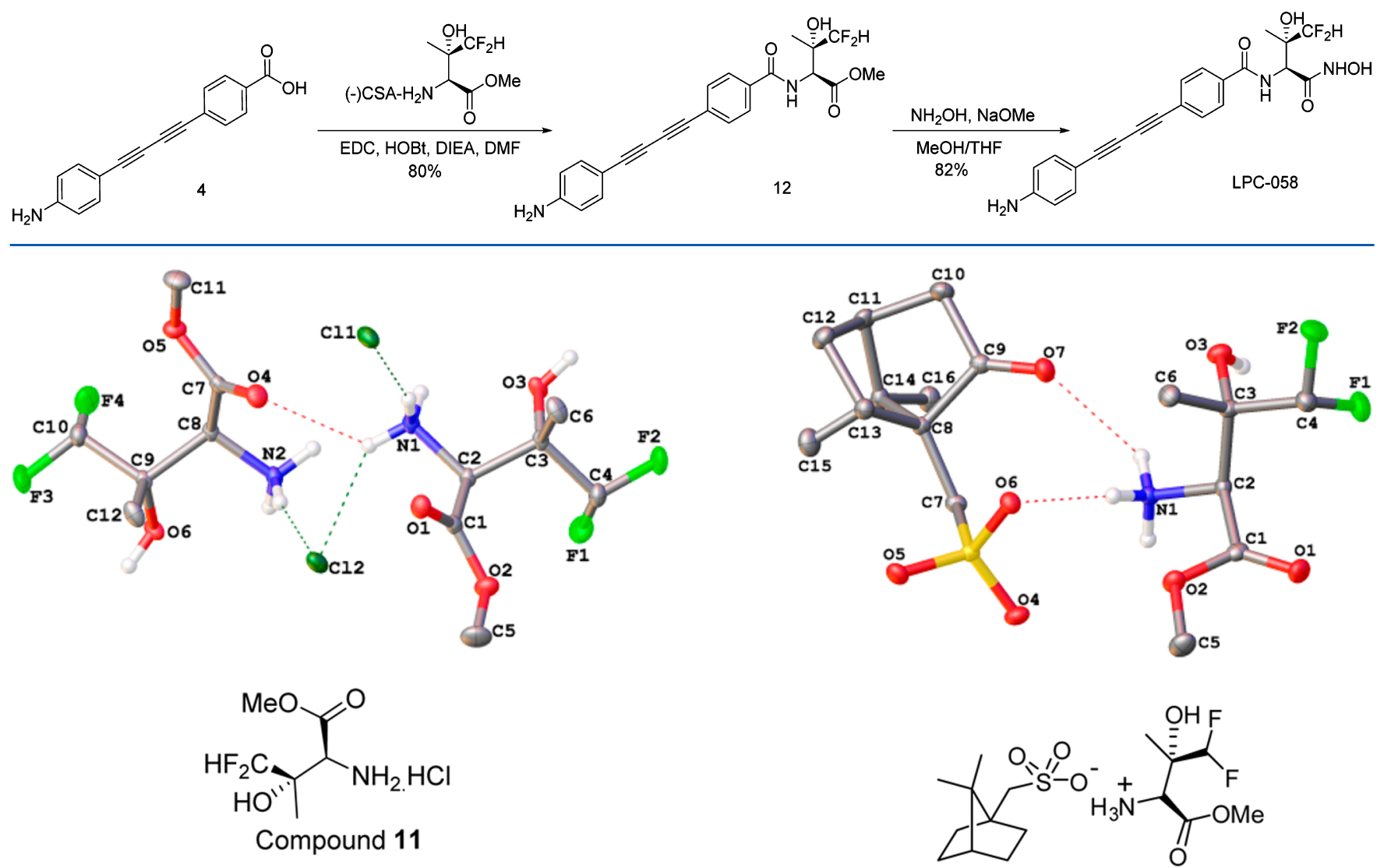

Compound 21

Figure 2. X-ray crystallographic structures of 11 and 21. The compounds are colored in the following atom colors: carbon, gray; nitrogen, blue; oxygen, red; sulfur, yellow; fluorine, green; chlorine, deep green.

selective manner. ${ }^{18}$ It is worth mentioning that the authors in that work have included entries of monofluoroacetone and trifluoroacetone reacting with methyl $\alpha$-isocyanoacetate to yield corresponding oxazolines stereoselectively in ratios of 71:29 and 99:1, respectively. Inspired by their results, we had hoped to obtain stereoselectivity somewhere between the aforementioned ratios when reacting difluoroacetone with methyl $\alpha$-isocyanoacetate as described in Scheme 3.

Difluoroacetone 17 was reacted with methyl $\alpha$-isocyanoacetate 18 to give the diastereomeric mixture of oxazolines $19 a$ and 19b. The reaction was performed in dry 1,1-dichloroethane (DCE) at ambient temperature in the presence of $4 \mathrm{~mol} \% \mathrm{CuCl}$ and $5 \mathrm{~mol} \%$ TEA. The ratio of oxazoline diastereomers 19a and $19 \mathrm{~b}$ is $87: 13$, which was determined by NMR chemical shifts of the crude reaction mixture after removal of the catalyst and solvent. Replacing DCE with DCM as the reaction solvent also provided similar results in terms of chemical yield and diastereoselectivity. Hydrolysis of the diastereomeric mixture of oxazolines 19a and $19 b$ in methanolic $\mathrm{HCl}$ at room temperature afforded the corresponding amino acid hydrochloride salts 20a and 20b. Desired diastereomer 20a was obtained in $>99 \%$ purity after recrystallizaion from a $\mathrm{MeOH} /$ MTBE solvent at room temperature with a chemical yield of $42 \%$. Alternatively, recrystallization can be accomplished from hot acetonitrile to provide 20 a in $56 \%$ yield and $>99 \%$ purity. To obtain optically pure $\mathbf{2 1}$, amino acid hydrochloride salt 20a was neutralized by $\mathrm{Na}_{2} \mathrm{CO}_{3}$ and the racemic free base was reacted with equimolar amounts of $R-(-)$-camphorsulfonic acid $[R-(-)-C S A]$ at room temperature in acetone. When the mixture was cooled, the desired amino ester 21 was obtained in $60 \%$ yield based on a single enantiomer with an optical purity of $>99 \%$. Optical purity was established using ${ }^{1} \mathrm{H}$ NMR and ${ }^{19} \mathrm{~F}$ NMR as follows: ${ }^{1} \mathrm{H}$ NMR and ${ }^{19} \mathrm{~F}$ NMR of racemic hydrochloride salt in the presence of a 10-fold excess of $(+)$-tartaric acid in $\mathrm{CD}_{3} \mathrm{OD}$ yielded a spectrum with wellresolved peaks. In particular, the $\alpha-\mathrm{CH}$, ester $\mathrm{CH}_{3}$, and ${ }^{19} \mathrm{~F}$ of the racemic methyl ester (Figure 1A,D) were well-resolved and readily identified when the spectra were recorded in the presence of excess tartaric acid (Figure 1B,E). It should be noted that ${ }^{1} \mathrm{H}$ NMR and ${ }^{19} \mathrm{~F}$ NMR of a recrystallized optically pure sample of $\mathbf{2 1}$ in the presence of a 10-fold excess of (+)-tartaric acid in $\mathrm{CD}_{3} \mathrm{OD}$ displayed only one set of peaks corresponding to the desired enantiomer (Figure 1C,F). The modified route to chiral amino ester $\mathbf{2 1}$ was shorter and cheaper than that described earlier for the corresponding hydrochloride salt $\mathbf{1 1}$ and was deemed suitable for large scale synthesis.

With multigram quantities of amino ester $\mathbf{2 1}$ and diacetylene carboxylic acid 4 in hand, we proceeded to the large scale synthesis of LPC-058 (Scheme 4). Amide coupling under EDC/HOBt conditions provided diacetylene ester 12 . Treatment of 12 with hydroxylamine and sodium methoxide at $0{ }^{\circ} \mathrm{C}$ provided hydroxamate LPC-058 in 67\% yield over two steps. It is noted that no epimerization at the $\alpha$-carbon was observed by LC-MS or NMR under these conditions. 
To determine the absolute configuration of $\mathbf{1 1}$ and 21, they were crystallized in methanol/MTBE and acetone solvents, respectively. The absolute configuration was determined by the measurement of the Flack parameter, which is calculated during the structural refinement. ${ }^{19,20}$ If the value is near 0 , the crystal is optically pure, in which case the absolute structure of the molecule can be determined with certainty by the X-ray data. In our study, the final refinement of the $\mathrm{Cu} \mathrm{K} \alpha$ data of the crystal of 11 and 21 resulted in Flack parameters of $0.0(0)$ and $-0.0(1)$, allowing an unambiguous assignment of the absolute structure as shown in Figure 2. The two chiral centers of 11, C-2 and C-3, and the four chiral centers of 21, C-2, C-3, C-8, and C-11, were thus determined to be $S$ and $S$ and $S, S, R$, and $S$, respectively. In summary, a short and scalable synthesis of hydroxamic acid derivative LPC-058 is described. The syntheses of key intermediates diacetylene carboxylic acid $\mathbf{4}$ and difluorothreonine methyl ester $\mathbf{2 1}$ were accomplished without any chromatography steps.

\section{EXPERIMENTAL SECTION}

Methyl 4-ethynylbenzoate, 4-ethylnylbenzenamine, 1,1-difluoroacetone, and methyl $\alpha$-isocyanoacetate were purchased from commercial vendors and used without further purification. LC-MS analysis was conducted on a HPLC instrument with a quadrapole mass analyzer and reverse phase C18 column $(4.6 \mathrm{~mm} \times 50 \mathrm{~mm}, 1.8 \mu \mathrm{m})$ with a water/ acetonitrile [each with $0.2 \%(\mathrm{v} / \mathrm{v})$ formic acid] gradient at a flow rate of $0.5 \mathrm{~mL} / \mathrm{min}$. The HRMS analyses were conducted on a TOF mass spectrometer using ESI mode. ${ }^{1} \mathrm{H},{ }^{13} \mathrm{C}$, and ${ }^{19} \mathrm{~F}$ spectra were recorded on 300 (or 400 ) $\mathrm{MHz}, 75$ (or 100) $\mathrm{MHz}$, and 282.4 (or 376.5) $\mathrm{MHz}$ spectrometers, respectively. Column chromatography was conducted using either silica gel flash chromatography or prepacked silica gel cartridges. All moisture-sensitive reactions were conducted using dry solvents under a slight pressure of ultrapure quality argon. Glassware was dried in an oven at $140{ }^{\circ} \mathrm{C}$ for at least $12 \mathrm{~h}$ prior to being used and then assembled quickly while hot, sealed with rubber septa, and allowed to cool under a stream of argon. Reaction mixtures were stirred magnetically using Teflon-coated magnetic stirring bars. Commercially available disposable syringes were used for transferring reagents and solvents.

Methyl 4-(Bromoethynyl)benzoate (16). ${ }^{17}$ To a solution of methyl 4-ethynylbenzoate $1(10.00 \mathrm{~g}, 62.5 \mathrm{mmol}, 1.0$ equiv) in acetone $(100 \mathrm{~mL})$ were added NBS $(12.24 \mathrm{~g}, 68.8 \mathrm{mmol}, 1.05$ equiv $)$ and $\mathrm{CF}_{3} \mathrm{CO}_{2} \mathrm{Ag}(0.53 \mathrm{~g}, 0.31 \mathrm{mmol}, 0.05$ equiv $)$ at room temperature under argon. The reaction mixture was stirred at room temperature for $2 \mathrm{~h}$. The resulting solution was concentrated to remove acetone. The residue was diluted with water $(100 \mathrm{~mL})$ and extracted with EtOAc (3 $\times 80 \mathrm{~mL})$. The combined organic layers were washed with water $(2 \times$ $60 \mathrm{~mL})$ and brine $(60 \mathrm{~mL})$ and dried over anhydrous $\mathrm{Na}_{2} \mathrm{SO}_{4}$. Evaporation of the solvent afforded the crude product that was purified by silica gel chromatography (eluting with EtOAc in hexane, $0-10 \%$ ) to give 16 as a white solid ( $12.4 \mathrm{~g}, 83 \%$ yield). ${ }^{1} \mathrm{H}$ NMR $(300 \mathrm{MHz}$, $\left.\mathrm{CDCl}_{3}\right): \delta 3.9(\mathrm{~s}, 3 \mathrm{H}), 7.50(\mathrm{~d}, J=8.1 \mathrm{~Hz}, 2 \mathrm{H}), 7.97(\mathrm{~d}, J=6.9 \mathrm{~Hz}$, $2 \mathrm{H}) .{ }^{13} \mathrm{C} \mathrm{NMR}\left(75 \mathrm{MHz}, \mathrm{CDCl}_{3}\right): \delta 52.3,53.4,79.4,127.3,129.5$, 129.9, 131.9, 166.3. MS (LC/MS, ESI): $m / z 240[\mathrm{M}+\mathrm{H}]^{+}$.

Methyl 4-[(4-Aminophenyl)buta-1,3-diyn-1-yl]benzoate (3). ${ }^{7}$ Copper(II) acetate $(0.45 \mathrm{~g}, 0.50 \mathrm{mmol}, 0.05$ equiv) was added at room temperature under a stream of argon to a stirred solution of methyl (4bromoethylnyl)benzoate ( $12.0 \mathrm{~g}, 50.0 \mathrm{mmol}, 1.00$ equiv), 4-ethynylaniline $2(6.20 \mathrm{~g}, 52.5 \mathrm{mmol}, 1.05$ equiv), and piperidine (12.77 g, 150.0 mmoL, 3.00 equiv) in $\mathrm{MeOH}$ ( $200 \mathrm{~mL}$, degassed with argon). The reaction mixture was stirred at room temperature for $20 \mathrm{~h}$. The resulting suspension was diluted with water $(400 \mathrm{~mL})$ and stirred for 30 min at room temperature. The mixture was filtered, and the filtered solid was washed with water $(2 \times 200 \mathrm{~mL})$. The solid obtained was dried to afford crude 3 ( $13.5 \mathrm{~g}$ ) as a yellow solid that was carried on to the next step without further purification. ${ }^{1} \mathrm{H}$ NMR $(300 \mathrm{MHz}$, DMSO$\left.d_{6}\right): \delta 3.83(\mathrm{~s}, 3 \mathrm{H}), 5.85(\mathrm{~s}, 2 \mathrm{H}), 6.54(\mathrm{~d}, J=8.1 \mathrm{~Hz}, 2 \mathrm{H}), 7.25(\mathrm{~d}, J=$
$8.4 \mathrm{~Hz}, 2 \mathrm{H}), 7.64(\mathrm{~d}, J=8.1 \mathrm{~Hz}, 2 \mathrm{H}), 7.92(\mathrm{~d}, J=8.1 \mathrm{~Hz}, 2 \mathrm{H}) .{ }^{13} \mathrm{C}$ NMR $\left(75 \mathrm{MHz}\right.$, DMSO- $\left.d_{6}\right): \delta 53.0,71.8,78.3,80.5,87.0,105.7,114.3$, $126.7,130.1,130.3,133.0,134.8,151.6,166.2$. MS (LC/MS, ESI): $m / z$ $276[\mathrm{M}+\mathrm{H}]^{+}$.

4-[(4-Aminophenyl)buta-1,3-diyn-1-yl]benzoic Acid (4). ${ }^{7}$ To a solution of crude compound 3 (13.5 g, $50.0 \mathrm{mmol}, 1.00$ equiv) in methanol $(100 \mathrm{~mL})$ was added $1 \mathrm{~N} \mathrm{NaOH}(100 \mathrm{~mL}, 100.0 \mathrm{mmol}, 2.00$ equiv) at room temperature under a stream of argon. The reaction mixture was heated to reflux for $1 \mathrm{~h}$. The solution was diluted with water $(100 \mathrm{~mL})$ and acidified with concentrated $\mathrm{HCl}$ to $\mathrm{pH} \sim 3$. The precipitate was filtered, washed with water, and dried under vacuum to give crude acid 4 ( $11.5 \mathrm{~g}$, two steps, $88 \%$ yield for two steps), which was carried to the next step without purification. ${ }^{1} \mathrm{H}$ NMR $(300 \mathrm{MHz}$, DMSO- $\left.d_{6}\right): \delta 6.95(\mathrm{~d}, J=8.4 \mathrm{~Hz}, 2 \mathrm{H}), 7.45(\mathrm{~d}, J=8.4 \mathrm{~Hz}, 2 \mathrm{H}), 7.66(\mathrm{~d}$, $J=8.4 \mathrm{~Hz}, 2 \mathrm{H}), 7.93(\mathrm{~d}, J=8.4 \mathrm{~Hz}, 2 \mathrm{H}) .{ }^{13} \mathrm{C}$ NMR $(75 \mathrm{MHz}$, DMSO$\left.d_{6}\right): \delta$ 73.0, 77.2, 81.2, 85.0, 112.0, 118.8, 125.8, 130.2, 131.9, 133.1, 134.6, 144.2, 167.2. MS (LC/MS, ESI): $m / z 262[\mathrm{M}+\mathrm{H}]^{+}$.

(4S,5S)-Methyl 5-(Difluoromethyl)-5-methyl-4,5-dihydrooxazole-4-carboxylate (19a). Methyl 2-isocyanoacetate (20.00 g, 201.8 mmol, 1.00 equiv) was added slowly to an ice-cold suspension of 1,1 difluoroacetone ( $22.78 \mathrm{~g}, 242.20 \mathrm{mmol}, 1.20$ equiv), $\mathrm{CuCl}(0.80 \mathrm{~g}, 8.10$ mmol, 0.04 equiv), and TEA ( $1.41 \mathrm{~mL}, 10.10 \mathrm{mmol}, 0.05$ equiv) in anhydrous DCM $(330 \mathrm{~mL})$ under argon. The reaction mixture was stirred at $0{ }^{\circ} \mathrm{C}$ and gradually warmed to room temperature overnight $(20 \mathrm{~h})$. The resulting solution was diluted with DCM $(150 \mathrm{~mL})$. The mixture was washed with $10 \%$ aqueous ammonia $(3 \times 100 \mathrm{~mL})$, water $(100 \mathrm{~mL})$, and brine $(100 \mathrm{~mL})$ and dried (anhydrous $\left.\mathrm{Na}_{2} \mathrm{SO}_{4}\right)$. Evaporation of the solvent afforded a crude mixture (86:14) of diastereomers 19a and $19 b$ (brown liquid, $35.5 \mathrm{~g}$, 91\% yield), which was carried to the next step without further purification. ${ }^{1} \mathrm{H}$ NMR (400 $\left.\mathrm{MHz} \mathrm{CDCl}_{3}\right): \delta 1.35(\mathrm{~s}, 3 \mathrm{H}), 1.54(\mathrm{~s}, 0.5 \mathrm{H}), 3.67(\mathrm{~s}, 0.5 \mathrm{H}), 3.74(\mathrm{~s}$, $3 \mathrm{H}), 4.47(\mathrm{~s}, 0.17 \mathrm{H}), 4.78(\mathrm{~s}, 1 \mathrm{H}), 5.69\left(\mathrm{t}, J_{\mathrm{HF}}=56 \mathrm{~Hz}, 1 \mathrm{H}\right), 5.88(\mathrm{t}$, $\left.J_{\mathrm{HF}}=56 \mathrm{~Hz}, 0.17 \mathrm{H}\right), 6.94(\mathrm{~s}, 1 \mathrm{H}) .{ }^{13} \mathrm{C} \mathrm{NMR}\left(100 \mathrm{MHz} \mathrm{CDCl}_{3}\right): \delta$ $15.4,43.4,52.5,114.2\left(\mathrm{t}, J_{\mathrm{CF}}=494 \mathrm{~Hz}\right), 168.7 .{ }^{19} \mathrm{~F}$ NMR $(376.5 \mathrm{MHz}$, $\left.\mathrm{CDCl}_{3}\right): \delta-132.83\left(\mathrm{~d}, J_{\mathrm{HF}}=56 \mathrm{~Hz}\right.$, major $),-131.40\left(\mathrm{ABq}, \mathrm{d}, 2 \mathrm{~F}, J_{\mathrm{HF}}=\right.$ $56 \mathrm{~Hz}, \mathrm{~J}_{\mathrm{FF}}=300 \mathrm{~Hz}$, minor). MS (LC/MS, ESI): $m / z 194[\mathrm{M}+\mathrm{H}]^{+}$.

Methyl 2-Amino-4,4-difluoro-3-hydroxy-3-methylbutanoate Hydrochloride (racemic 20a). To a stirred solution of oxazoline 19a and $19 \mathrm{~b}(35.30 \mathrm{~g}, 182.70 \mathrm{mmol}, 1.00$ equiv) in methanol $(180 \mathrm{~mL})$ kept at room temperature in a water bath under argon was added dropwise concentrated $\mathrm{HCl}(36 \mathrm{~mL})$. The reaction mixture was stirred at room temperature for $14 \mathrm{~h}$. The resulting solution was concentrated to dryness. The residue was diluted with MTBE $(400 \mathrm{~mL})$ and stirred vigorously for $2 \mathrm{~h}$. The suspension was concentrated to afford crude 20a and 20b as a light brown solid. ${ }^{1} \mathrm{H}$ NMR (400 MHz, $\left.\mathrm{CD}_{3} \mathrm{OD}\right): \delta$ $1.30(\mathrm{~s}, 3 \mathrm{H}), 1.48(\mathrm{~s}, 0.5 \mathrm{H}), 3.85(\mathrm{~s}, 0.5 \mathrm{H}), 3.86(\mathrm{~s}, 3 \mathrm{H}), 4.15(\mathrm{~s}$, $0.17 \mathrm{H}), 4.16(\mathrm{~s}, 1 \mathrm{H}), 5.95\left(\mathrm{t}, J_{\mathrm{HF}}=56 \mathrm{~Hz}, 0.17 \mathrm{H}\right), 5.99\left(\mathrm{t}, J_{\mathrm{HF}}=56 \mathrm{~Hz}\right.$, 1H). ${ }^{19} \mathrm{~F}$ NMR $\left(376.5 \mathrm{MHz}, \mathrm{CD}_{3} \mathrm{OD}\right): \delta-134.25,-135.15$ (ABq, d, $\left.2 \mathrm{~F}, J_{\mathrm{HF}}=56 \mathrm{~Hz}, J_{\mathrm{FF}}=301 \mathrm{~Hz}\right) .{ }^{13} \mathrm{C} \mathrm{NMR}\left(100 \mathrm{MHz}, \mathrm{CD}_{3} \mathrm{OD}\right): \delta 15.9$, $52.6,55.9,71.2\left(\mathrm{t},{ }^{2} J_{\mathrm{CF}}=42.5 \mathrm{~Hz}\right), 115.4\left(\mathrm{t}, J_{\mathrm{CF}}=491 \mathrm{~Hz}\right), 166.7$. MS (LC/MS, ESI): $m / z 184[\mathrm{M}+\mathrm{H}]^{+}$. The crude product was dissolved to $\sim 55 \mathrm{~mL}$ of methanol and MTBE $(\sim 270 \mathrm{~mL})$ at room temperature. Then the solution was left at $-20^{\circ} \mathrm{C}$ for 2 days to give the racemic 20a $(17.00 \mathrm{~g}, 42 \%$ yield $)$ as an off-white solid. Alternatively, a crude mixture of 20a and $20 \mathrm{~b}$ can be recrystallized from hot acetonitrile $(\sim 200 \mathrm{~mL})$ to provide racemic 20a in $56 \%$ yield. Mp: $142{ }^{\circ} \mathrm{C} .{ }^{1} \mathrm{H}$ NMR $(400 \mathrm{MHz}$, $\left.\mathrm{CD}_{3} \mathrm{OD}\right): \delta 1.30(\mathrm{~s}, 3 \mathrm{H}), 3.87(\mathrm{~s}, 3 \mathrm{H}), 4.16(\mathrm{~s}, 1 \mathrm{H}), 5.99\left(\mathrm{t}, J_{\mathrm{HF}}=56\right.$ $\mathrm{Hz}, 1 \mathrm{H}) .{ }^{19} \mathrm{~F}$ NMR $\left(376.5 \mathrm{MHz}, \mathrm{CD}_{3} \mathrm{OD}\right): \delta-134.25,-135.15(\mathrm{ABq}$, d, $\left.2 \mathrm{~F}, J_{\mathrm{HF}}=56 \mathrm{~Hz}, J_{\mathrm{FF}}=301 \mathrm{~Hz}\right) .{ }^{13} \mathrm{C} \mathrm{NMR}\left(100 \mathrm{MHz}, \mathrm{CD}_{3} \mathrm{OD}\right): \delta$ 15.9, 52.6, 56.0, 71.2 $\left(\mathrm{t},{ }^{2} J_{\mathrm{CF}}=42.5 \mathrm{~Hz}\right), 115.4\left(\mathrm{t}, J_{\mathrm{CF}}=490 \mathrm{~Hz}\right) .{ }^{19} \mathrm{~F}$ $\operatorname{NMR}\left(376 \mathrm{MHz}, \mathrm{CDCl}_{3}\right): \delta-134.70$. HRMS (ESI/TOF): $m / z[\mathrm{M}+$ $\mathrm{H}]^{+}$calcd for $\mathrm{C}_{6} \mathrm{H}_{12} \mathrm{~F}_{2} \mathrm{NO}_{3} 184.0785$, found 184.0776 .

(2S,3S)-Methyl 2-Amino-4,4-difluoro-3-hydroxy-3-methylbutanoate (-)-CSA (21). To an ice bath-cooled solution of racemic 20 (16.70 g, $76.00 \mathrm{mmol}, 1.00$ equiv) in water $(100 \mathrm{~mL})$ was added $\mathrm{Na}_{2} \mathrm{CO}_{3}(24.17 \mathrm{~g}, 228.00 \mathrm{mmol}, 3.00$ equiv) under argon. The reaction mixture was stirred at room temperature for $1 \mathrm{~h}$. Then the resulting solution was extracted with EtOAc $(6 \times 100 \mathrm{~mL})$. The combined organic layers were dried over anhydrous $\mathrm{Na}_{2} \mathrm{SO}_{4}$. Evaporation of the solvent afforded the free amine (14.0 g) as a light brown liquid. The 
free amine ( $13.50 \mathrm{~g}, 73.7 \mathrm{mmol}, 1.00$ equiv) was dissolved in acetone $(100 \mathrm{~mL})$, and (1R)-(-)-10-camphorsulfonic acid (17.12 g, 73.70 mmol, 1.00 equiv) was added. The mixture was stirred at room temperature overnight. The white solid was filtered and washed with acetone $(20 \mathrm{~mL})$ and dried to give (-)-CSA salt 21 ( $8.40 \mathrm{~g}, 28 \%$ yield). Mp: $160{ }^{\circ} \mathrm{C} .[\alpha]^{\mathrm{D}}=-24.1(c=0.4 ; \mathrm{MeOH}) .{ }^{1} \mathrm{H}$ NMR $(400 \mathrm{MHz}$, $\left.\mathrm{CD}_{3} \mathrm{OD}\right): \delta 0.83(\mathrm{~s}, 3 \mathrm{H}), 1.09(\mathrm{~s}, 3 \mathrm{H}), 1.30(\mathrm{~s}, 3 \mathrm{H}), 1.37-1.42(\mathrm{~m}$, $1 \mathrm{H}), 1.57-1.64(\mathrm{~m}, 1 \mathrm{H}), 1.88(\mathrm{~d}, J=18.4 \mathrm{~Hz}, 1 \mathrm{H}), 2.00-2.04(\mathrm{~m}$, $2 \mathrm{H}), 2.29-2.35(\mathrm{~m}, 1 \mathrm{H}), 2.57-2.61(\mathrm{~m}, 1 \mathrm{H}), 2.76(\mathrm{~d}, J=14.8 \mathrm{~Hz}$, $1 \mathrm{H}), 3.86(\mathrm{~s}, 3 \mathrm{H}), 4.21(\mathrm{~s}, 1 \mathrm{H}), 5.98\left(\mathrm{t}, J_{\mathrm{HF}}=56 \mathrm{~Hz}, 1 \mathrm{H}\right) .{ }^{19} \mathrm{~F}$ NMR (376.5 MHz, CD $\left.{ }_{3} \mathrm{OD}\right): \delta-134.23,-135.13\left(\mathrm{ABq}, \mathrm{d}, 2 \mathrm{~F}, J_{\mathrm{HF}}=56 \mathrm{~Hz}\right.$, $\left.J_{\mathrm{FF}}=301 \mathrm{~Hz}\right) .{ }^{13} \mathrm{C}$ NMR $\left(100 \mathrm{MHz}, \mathrm{CD}_{3} \mathrm{OD}\right): \delta 5.8,18.7,19.0,24.3$, 26.4, 42.2, 42.6, 46.8, 52.6, 56.0, 58.2, $71.2\left(\mathrm{t},{ }^{2} J_{\mathrm{CF}}=42.5 \mathrm{~Hz}\right), 115.4(\mathrm{t}$, $\left.J_{\mathrm{CF}}=491 \mathrm{~Hz}\right), 166.7,218.1 .{ }^{19} \mathrm{~F} \mathrm{NMR}\left(376 \mathrm{MHz} \mathrm{CDCl}_{3}\right): \delta-134.68$ $\left(\mathrm{t}, J_{\mathrm{HF}}=56 \mathrm{~Hz}\right)$. HRMS (ESI/TOF): $\mathrm{m} / z[\mathrm{M}+\mathrm{H}]^{+}$calcd for $\mathrm{C}_{6} \mathrm{H}_{12} \mathrm{~F}_{2} \mathrm{NO}_{3}$ 184.0785, found 184.0781.

(2S,3S)-Methyl 2-\{4-[(4-Aminophenyl)buta-1,3-diyn-1-yl]benzamido\}-4,4-difluoro-3-hydroxy-3-methylbutanoate (12). ${ }^{4}$ To a solution of diacetylene carboxylic acid $4(3.00 \mathrm{~g}, 12.49 \mathrm{mmol})$ in anhydrous DMF $(25 \mathrm{~mL})$ were added amino ester 21 (5.40 g, 13.11 mmol, 1.05 equiv), $\mathrm{EDC}-\mathrm{HCl}(2.64 \mathrm{~g}, 13.80 \mathrm{mmol}, 1.2$ equiv), and HOBt ( $1.87 \mathrm{~g}, 13.80 \mathrm{mmol}, 1.2$ equiv) at room temperature under argon. The mixture was cooled to $0{ }^{\circ} \mathrm{C}$, and DIEA $(8.1 \mathrm{~mL}, 45.90$ mmol, 4.00 equiv) was added. The reaction mixture was stirred at $0{ }^{\circ} \mathrm{C}$ for $2 \mathrm{~h}$ and then allowed to warm to room temperature for $14 \mathrm{~h}$. The yellow solution was then concentrated to dryness. The residue was treated with water $(100 \mathrm{~mL})$ and extracted with EtOAc $(3 \times 80 \mathrm{~mL})$. The combined extracts were washed with water $(80 \mathrm{~mL})$ and brine $(80$ $\mathrm{mL}$ ) and dried (anhydrous $\mathrm{Na}_{2} \mathrm{SO}_{4}$ ). The crude product was purified by silica gel chromatography (eluting with $\mathrm{MeOH}$ in DCM, $0-2.5 \%$ ) to give 12 as a yellow solid $(4.23 \mathrm{~g}, 80 \%)$. Mp: $167-168^{\circ} \mathrm{C} \mathrm{dec}$. $[\alpha]_{25}^{\mathrm{D}}$ $=+28.2(c=0.2 ; \mathrm{MeOH}) .{ }^{1} \mathrm{H}$ NMR $\left(300 \mathrm{MHz}, \mathrm{CD}_{3} \mathrm{OD}\right): \delta 1.37(\mathrm{~d}, J$ $=2.1 \mathrm{~Hz}, 3 \mathrm{H}), 3,76(\mathrm{~s}, 3 \mathrm{H}), 4.267(\mathrm{dd}, J=9.3,19.5 \mathrm{~Hz}, 1 \mathrm{H}), 4.42(\mathrm{dd}, J$ $=9.3,19.8 \mathrm{~Hz}, 1 \mathrm{H}), 4.81(\mathrm{~s}, 1 \mathrm{H}), 5.85\left(\mathrm{t}, J_{\mathrm{HF}}=56 \mathrm{~Hz}, 1 \mathrm{H}\right), 6.61(\mathrm{~d}, J=$ $8.4 \mathrm{~Hz}, 2 \mathrm{H}), 7.24(\mathrm{~d}, J=8.4 \mathrm{~Hz}, 2 \mathrm{H}), 7.56(\mathrm{~d}, J=8.1 \mathrm{~Hz}, 2 \mathrm{H}), 7.82(\mathrm{~d}, J$ $=8.1 \mathrm{~Hz}, 2 \mathrm{H}) .{ }^{19} \mathrm{~F}$ NMR $\left(400 \mathrm{MHz}, \mathrm{CD}_{3} \mathrm{OD}\right): \delta-131.06,-137.61$ $\left(\mathrm{ABq}, \mathrm{d}, 2 \mathrm{~F}, J_{\mathrm{HF}}=56 \mathrm{~Hz}, J_{\mathrm{FF}}=300 \mathrm{~Hz}\right) \cdot{ }^{13} \mathrm{C} \mathrm{NMR}\left(75 \mathrm{MHz}, \mathrm{CD}_{3} \mathrm{OD}\right)$ : $\delta$ 20.5, 51.7, 70.9, (71.9, 72.2), 76.9, 79.1, 84.7, (85.5, 87.8), 108.3, $114.3,126.2,127.2,127.6,132.2,133.6,133.9,150.2,168.2,170.6 . \mathrm{MS}$ (LC/MS, ESI): $m / z 427[\mathrm{M}+\mathrm{H}]^{+}$. HRMS (ESI/TOF): $m / z[\mathrm{M}]^{+}$ calcd for $\mathrm{C}_{23} \mathrm{H}_{20} \mathrm{~F}_{2} \mathrm{~N}_{2} \mathrm{O}_{4} 426.1391$, found 426.1392 .

4-[(4-Aminophenyl)buta-1,3-diyn-1-yl]- $N-[(2 S, 3 S)-4,4-d i-$ fluoro-3-hydroxy-1-(hydroxyamino)-3-methyl-1-oxobutan-2yl]benzamide (LPC-058). ${ }^{4}$ To an ice-cold solution of 12 (4.00 g, 9.4 $\mathrm{mmol})$ dissolved in anhydrous $\mathrm{MeOH}(15 \mathrm{~mL})$ and THF $(15 \mathrm{~mL})$ was added hydroxylamine hydrochloride $(3.27 \mathrm{~g}, 46.9 \mathrm{mmol}, 5.0$ equiv) followed by $25 \%$ sodium methoxide in a methanol solution $(16.0 \mathrm{~mL}$, $70.50 \mathrm{mmol}, 7.5$ equiv). The reaction mixture was stirred under argon at $0{ }^{\circ} \mathrm{C}$ for $2 \mathrm{~h}$ and then allowed to warm to ambient temperature while stirring was continued overnight $(14 \mathrm{~h})$. The resulting yellow suspension was condensed to dryness with a rotary evaporator, and the residue obtained was treated with water $(200 \mathrm{~mL})$ and saturated $\mathrm{NH}_{4} \mathrm{Cl}(80 \mathrm{~mL})$ and extracted with EtOAc $(3 \times 100 \mathrm{~mL})$. The combined extracts were washed with water $(80 \mathrm{~mL})$ and brine $(80 \mathrm{~mL})$ and dried over anhydrous $\mathrm{Na}_{2} \mathrm{SO}_{4}$. Evaporation of the solvent afforded the crude product, which was purified by silica gel chromatography (eluting with $0-5 \% \mathrm{MeOH}$ in DCM) to afford the title compound as a yellow solid (3.29 g, 82\% yield). Mp: $155-157^{\circ} \mathrm{C} \mathrm{dec}$. $[\alpha]^{\mathrm{D}}{ }_{25}=+61.2$ $(c=0.4 ; \mathrm{MeOH}) .{ }^{1} \mathrm{H}$ NMR $\left(300 \mathrm{MHz}, \mathrm{CD}_{3} \mathrm{OD}\right): \delta 1.36(\mathrm{~s}, 3 \mathrm{H}), 4.73$ $(\mathrm{s}, 1 \mathrm{H}), 5.80\left(\mathrm{t}, J_{\mathrm{HF}}=56 \mathrm{~Hz}, 1 \mathrm{H}\right), 6.61(\mathrm{~d}, J=8.7 \mathrm{~Hz}, 2 \mathrm{H}), 7.24(\mathrm{~d}, J=$ $8.7 \mathrm{~Hz}, 2 \mathrm{H}), 7.57(\mathrm{~d}, J=8.1 \mathrm{~Hz}, 2 \mathrm{H}), 7.82(\mathrm{~d}, J=8.4 \mathrm{~Hz}, 2 \mathrm{H}) .{ }^{19} \mathrm{~F}$ $\operatorname{NMR}\left(400 \mathrm{MHz}, \mathrm{CD}_{3} \mathrm{OD}\right): \delta-130.00,-137.91\left(\mathrm{ABq}, \mathrm{d}, 2 \mathrm{~F}, J_{\mathrm{HF}}=56\right.$ $\left.\mathrm{Hz}, J_{\mathrm{FF}}=300 \mathrm{~Hz}\right) .{ }^{13} \mathrm{C}$ NMR $\left(75 \mathrm{MHz}, \mathrm{CD}_{3} \mathrm{OD}\right): \delta 16.5,54.9,70.8$, (72.6, 72.9, 73.2), 76.8, 79.0, 84.7, 108.4, (112.7, 116.0, 119.2), 114.3, $126.3,127.5,132.2,133.5,133.8,150.2,166.5,167.5$. MS (LC/MS, ESI): $m / z 428.2[\mathrm{M}+\mathrm{H}]^{+}$. HRMS (ESI/TOF): $m / z[\mathrm{M}]^{+}$calcd for $\mathrm{C}_{22} \mathrm{H}_{19} \mathrm{~F}_{2} \mathrm{~N}_{3} \mathrm{O}_{4}$ 427.1344, found 427.1346.

\section{ASSOCIATED CONTENT}

\section{Supporting Information}

The Supporting Information is available free of charge on the ACS Publications website at DOI: 10.1021/acs.joc.6b00589.

Crystallographic data for 11 (CIF)

Crystallographic data for $\mathbf{2 1}$ (CIF)

${ }^{1} \mathrm{H},{ }^{13} \mathrm{C}$, and wherever applicable ${ }^{19} \mathrm{~F}$ NMR spectra of all compounds synthesized (PDF)

\section{AUTHOR INFORMATION}

\section{Corresponding Authors}

*E-mail: ramegop@gmail.com.

*E-mail: peizhou@biochem.duke.edu.

\section{Notes}

The authors declare no competing financial interest.

\section{ACKNOWLEDGMENTS}

This work was supported by National Institutes of Health Grants AI055588, AI094475, and GM115355 awarded to P.Z. We thank Dr. Kalpathy Santhosh for experimental assistance.

\section{REFERENCES}

(1) Vergidis, P. I.; Falagas, M. E. Curr. Opin. Invest. Drugs 2008, 9, 176.

(2) Boucher, H. W.; Talbot, G. H.; Bradley, J. S.; Edwards, J. E.; Gilbert, D.; Rice, L. B.; Scheld, M.; Spellberg, B.; Bartlett. Clin. Infect. Dis. 2009, 48, 1.

(3) Cooper, M. A.; Shlaes, D. Nature 2011, 472, 32.

(4) Lee, C. J.; Liang, X. F.; Wu, Q. L.; Najeeb, J.; Zhao, J.; Gopalaswamy, R.; Titecat, M.; Sebbane, F.; Lemaitre, N.; Toone, E. J.; Zhou, P. Nat. Commun. 2016, 7, 10638.

(5) Glaser, C. Ber. Dtsch. Chem. Ges. 1869, 2, 422.

(6) Nicolaou, K. C.; Zipkin, R. E.; Petasis, N. A. J. Am. Chem. Soc. 1982, 104, 5558.

(7) Liang, X. F.; Lee, C. J.; Chen, X.; Chung, H. S.; Zeng, D. N.; Raetz, C.; Li, Y.; Zhou, P.; Toone, E. J. Bioorg. Med. Chem. 2011, 19, 852.

(8) Arnone, A.; Gestmann, D.; Meille, S. V.; Resnati; Sidoti, G. Chem. Commun. 1996, 22, 2569.

(9) Drabowicz, J.; Oae, S. Synthesis 1977, 1977, 404.

(10) Nishide, K.; Shigeta, Y.; Obata, K.; Inoue, T.; Node, M. Tetrahedron Lett. 1996, 37, 2271.

(11) Zhao, S. H.; Samuel, O.; Kagan, H. B. Organic Syntheses 1993, 8, 464.

(12) Balaraman, K.; Kesavan, V. Synthesis 2010, 2010, 3461.

(13) Nye, S. A.; Potts, K. T. Synthesis 1988, 1988, 375.

(14) Weng, Y.; Cheng, B.; He, C.; Lei, A. Angew. Chem., Int. Ed. 2012, $51,9547$.

(15) Jiang, H. F.; Wang, A. Z. Synthesis 2007, 2007, 1649.

(16) Paixão, M. W.; Weber, M.; Braga, A. L.; de Azeredo, J. B.; Deobald, A. M.; Stefani, H. A. Tetrahedron Lett. 2008, 49, 2366.

(17) Karad, S. N.; Liu, R. S. Angew. Chem., Int. Ed. 2014, 53, 9072.

(18) Soloshonok, V. A.; Kacharov, A. D.; Avilov, D. V.; Ishikawa, K.; Nagashima, N. J.; Hayashi, T. J. Org. Chem. 1997, 62, 3470.

(19) Flack, H. D.; Bernardinelli, G. Chirality 2008, 20, 681.

(20) Flack, H. D. Acta Crystallogr., Sect. A: Found. Crystallogr. 1983, 39, 876.

\section{NOTE ADDED AFTER ASAP PUBLICATION}

Figures 1 and 2 were corrected on May 11, 2016. 